\title{
Study and Realization of Supplier Business Intelligence System for Chain Supermarket
}

\author{
Hong Xue, Peiyuan Guo, Huiyan Zhang, Binbin Kang \\ College of Computer and Information Engineering \\ Beijing Technology and Business University \\ Beijing, China \\ e-mail: hongxue6@yahoo.com.cn
}

\begin{abstract}
With the supplier data of supermarket, the business intelligence system was developed. The paper made use of data guiding into and guiding out service tool of Microsoft SQL Server 2005 as ETL tool. A mass of data needed for analyzing and decisionmaking were separated from affair database by taking out, transition, cleanout, loading. The data warehouse facing supplier theme was established by Microsoft Analysis Services developing system. Online analytical processing system was designed. Supplier management Agent managed the data of supplier data warehouse and incepted the information that distribution center Agent sent out. It combined the data mining algorithm of clustering analysis to choose type of suppliers and informed distribution center Agent. The business intelligence system made furthest use of data in the supermarket corporation affair database, transformed them into information and then sublimed the information into knowledge. The system provides effective support for decision-making of governor in supermarket supplier management.
\end{abstract}

Keywords-supplier; business intelligence; supermarket; data mining; Agent technique

\section{INTRODUCTION}

Supplier management is an import link in the supply chain of retail trade, which is based on full and effective management to the supplier information of corporation and provides comprehensive management and support for the actuality, providing product or service, information communion, symbiosis, correlation operation decision-making of suppliers. The paper studied the supplier business intelligence system for chain supermarket based on the data warehouse, OLAP, data mining, business intelligence, artificial intelligence and Agent key technique. The system provides effective support for decision-making of governor in supermarket supplier management.

\section{DESIGN OF DATA WAREHOUSE}

Because data warehouse was the base of supplier business intelligence system for whole chain supermarket, its structure design played an important part in implementing of the system. The paper made use of data guiding into and guiding out service tool of Microsoft SQL Server 2005 as ETL tool. A mass of data needed for analyzing and decision-making were separated from affair database by taking out, transition, cleanout, loading. The data warehouse facing supplier theme was established by Microsoft Analysis Services developing system [1].

\section{A. Design of the information bag figure for supplier data warehouse}

The information bag figure of the data warehouse facing supplier theme was established by the method of packing information, which is showed in Fig. 1.Snowflake model was adopted in the system, because many dimensionalities had complicated arrangement structures.

\section{B. Design of fact table, dimension tables and metadata models}

The fact table was situated in center of multidimensional data model and was biggest table in supplier data warehouse. It recorded plentiful particular information of basic operation, which included the main keys and measurement values of correlative dimension tables. The structure of supplier fact table is showed in table I .In the system, supplier dimension table, merchandise dimension table, time dimension table and store dimension table were established by function design [2].

\begin{tabular}{|c|c|c|c|}
\hline Time & Store & Commodity & Supplier \\
\hline Year & Name & Name & Name \\
\hline Season & City & Brand & City \\
\hline Month & Province & $\begin{array}{l}\text { Secondary } \\
\text { category }\end{array}$ & Province \\
\hline Weak & State & Category & State \\
\hline \multirow[t]{5}{*}{ Day } & Address & Department & Type \\
\hline & Manager & Division & \\
\hline & Post code & & \\
\hline & Tel. Num. & & \\
\hline & $\begin{array}{l}\text { Opening } \\
\text { Time }\end{array}$ & & \\
\hline \multicolumn{4}{|c|}{$\begin{array}{l}\text { Measurement: Speak for quantity, Supply quantity, } \\
\text { Supply time, Supplier sale, Supplier cost, Price of } \\
\text { having invoice }\end{array}$} \\
\hline
\end{tabular}

Figure 1. The information bag figure of supplier data warehouse

\footnotetext{
* This paper was supported by the Education Committee Foundation of Beijing (200809) and (KM200610011006).
} 
TABLE I. STRUCTURE OF SUPPLIER FACT TABLE

\begin{tabular}{|l|l|l|}
\hline Word sect name & Data types & Explanation \\
\hline TimeId & Int(4) & Time code \\
\hline MerchandiseId & Int(4) & Merchandise code \\
\hline SupplierId & Int(4) & Supplier code \\
\hline StoreId & Int(4) & Store code \\
\hline SpeakQuantity & float(8) & Speaking for quantity \\
\hline SupplyQuantity & float(8) & Supply quantity \\
\hline SupplierSales & float(8) & Supplier sale \\
\hline SupplierCosts & money(8) & Supplier cost \\
\hline SupplyTime & smallint(2) & Supply time \\
\hline Store Price & money(8) & $\begin{array}{l}\text { Merchandise price of } \\
\text { having invoice }\end{array}$ \\
\hline
\end{tabular}

Metadata describes object attributes and all information related to the object. The metadata of object was saved in repository when the object was established by Analysis Services developing system. The supermarket supplier data warehouse included mostly theme metadata model, fact metadata model, dimension metadata model and data member metadata model. The theme metadata model is showed in table II.

\section{DESIGN OF ON-LINE ANALYTICAL PROCESSING SYSTEM}

\section{A. Establishment of multidimensional data volume}

Design work for on-line analytical processing system was mostly to establish multidimensional data volume. The data were pretreated by transforming and clearing. Then they were loaded into SQL database. The system used the guide provided by Analysis Manager to establish multidimensional data volume of data warehouse and connect data source.

In the system, MOLAP data storage type was chosen and aggregation was established in Set Aggregation Options faceplate. To intercalate appropriate aggregation options weighed memory space and performances [3]. The data can be observed from arbitrary angle by "browsing data" menu option of system, which is showed in Fig. 2.

TABLE II. METADATA TABLE OF SUPPLIER THEME

\begin{tabular}{|l|l|}
\hline Name & Supplier \\
\hline Description & $\begin{array}{l}\text { Supplier data of supplier management } \\
\text { department recording }\end{array}$ \\
\hline Purpose & Analyzing supplier status \\
\hline Dimension & Time, merchandise, store, supplier \\
\hline Fact & Supplier fact table \\
\hline $\begin{array}{l}\text { Measurement } \\
\text { values }\end{array}$ & $\begin{array}{l}\text { Speaking for quantity, Supply quantity, } \\
\text { Supply time, Supplier sale, Supplier cost, } \\
\text { Price of having invoice }\end{array}$ \\
\hline
\end{tabular}

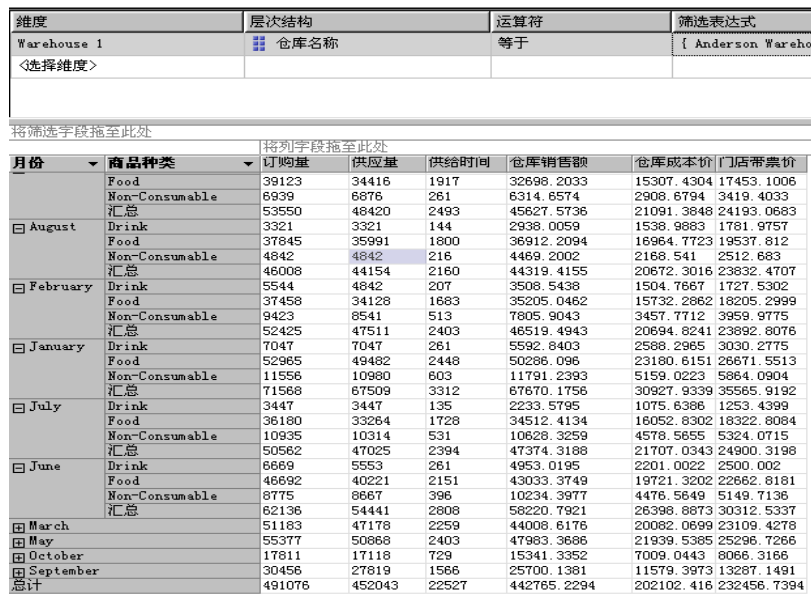

Figure 2. Browse of system multidimensional data

Considering the measurement factors of Speaking for quantity, Supply quantity, Supply time, Supplier sale, Supplier cost, Price of having invoice, on-line analytical processing can be implemented after supplier multidimensional data volume was established by time dimension, supplier dimension, merchandise dimension, store dimension.

\section{B. Design of on-line analytical processing}

Using Cube Browser control part in Visual Basic may realize the OLAP operation to the multidimensional data volume. Level of a dimension was spread or contracted by double-clicking on the sign $(+)$ in the table. It may increase a dimensionality or replace a displaying dimensionality that a dimension or a measurement above window was dragged to grid below it. Different combined forms of dimensionality and measurement were defined as slice of the multidimensional data volume. The data of the multidimensional data volume can be observed from different angles when position of any dimension was changed, which realized circumrotating. Drilling was a process in which analysis server returned some data which have been combined with structure of the multidimensional data volume. System will return the data producing the aggregations by a form of the simple record volume, when we knocked right on any cell and then chose drilling, which is showed in Fig. 3.

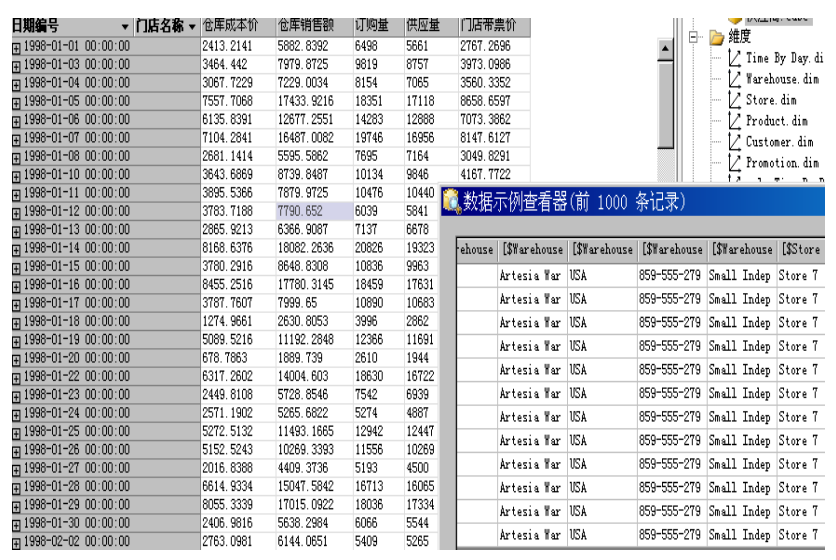

Figure 3. Drilling operation of system multidimensional data 


\section{CLUSTERING ANALYSIS OF SUPPLIER CLASSIFICATION}

Retail enterprises have abroad used ERP and POS systems to support operation of store and headquarters. They added up a mass of data in daily management, from which impersonality knowledge can be mined to class and estimate supplier.

The core idea of K-means algorithm is that $\mathrm{n}$ data objects are divided into $\mathrm{k}$ clustering, which obtains least square sum of the distances between the data and the clustering center point. K-means algorithm is as follows [4]:

Input: clustering number $\mathrm{k}$, data volume having $\mathrm{n}$ data objects.

Output: k clustering.

1) The $k$ objects are chosen from $n$ data objects, which are regarded as primary clustering center points.

2) The distance between every object and each clustering center point is calculated respectively and then this object is come under the clustering that closest clustering center point belongs to.

3) The $k$ clustering center points are recalculated after all objects are allotted.

4) If the calculated clustering center point is fully same with old clustering center point, calculating course converges and classification function goes fixed value. Here, classification is accomplished. Otherwise calculating course of step two is repeated.

5) The results of clustering are exported.
Supplier was regarded as the mining structure key in supplier multidimensional data volume. Merchandise dimension was regarded as nested table. The kind of merchandise was regarded as the key of nested table. Speaking for quantity, Supply quantity, Supplier cost, Supplier sale were regarded as input properties in three kinds of merchandises that are drink, food, rest consumable. The data were identified and classed by clustering method [5]. The clustering results are showed in table III.

Class 1 and class 3 belong to a big class and other classes belong to another big class when speaking for quantity of drink is more than 14492. Class 1 and class 3 belong to a big class and other classes belong to another big class when speaking for quantity of food is more than 107189. Class 1 and class 3 belong to a big class and other classes belong to another big class when speaking for quantity of rest consumable is more than 28178. Here, the suppliers of class 1 and class 3 are mostly chosen. Other classes are chosen when other things appear. The suppliers were evaluated by supplier sale, supplier cost, price of having invoice when a big class was chosen.

\section{DESIGN AND REALIZATION OF SUPPLIER MANAGEMENT AGENT}

Supplier management Agent managed the data of supplier data warehouse and incepted the information that distribution center Agent sent out. It combined the data mining algorithm of clustering analysis to choose type of suppliers and informed distribution center Agent [6].

TABLE III. CLUSTERING RESULTS OF SUPPLIERS

\begin{tabular}{|c|c|c|c|c|c|c|c|c|}
\hline & Class 1 & Class 2 & Class 3 & Class 4 & Class 5 & Class 6 & Class 7 & Class 8 \\
\hline $\begin{array}{l}\text { Drink speaking for } \\
\text { quantity }\end{array}$ & $\begin{array}{l}26269 \\
\pm 2455\end{array}$ & $\begin{array}{r}2071 \\
\pm 1422 \\
\end{array}$ & $\begin{array}{l}17616 \\
\pm 942 \\
\end{array}$ & $\begin{array}{r}10475 \\
\pm 750 \\
\end{array}$ & $\begin{array}{r}8302 \\
\pm 2564\end{array}$ & $\begin{array}{l}9643 \\
\pm 897 \\
\end{array}$ & $\begin{array}{c}6073 \\
\pm 2521 \\
\end{array}$ & $\begin{array}{r}7542 \\
\pm 0\end{array}$ \\
\hline Drink supply quantity & $\begin{array}{l}23506 \\
\pm 2343 \\
\end{array}$ & $\begin{array}{r}2071 \\
\pm 1422 \\
\end{array}$ & $\begin{array}{r}16488 \\
\pm 1442 \\
\end{array}$ & $\begin{array}{r}10143 \\
\pm 572 \\
\end{array}$ & $\begin{array}{r}7573 \\
\pm 2106 \\
\end{array}$ & $\begin{array}{l}9260 \\
\pm 725 \\
\end{array}$ & $\begin{array}{c}7573 \\
\pm 2744 \\
\end{array}$ & $\begin{array}{r}6777 \\
\pm 0\end{array}$ \\
\hline Drink supplier cost & $\begin{array}{l}9023 \\
\pm 1047 \\
\end{array}$ & $\begin{array}{r}915 \\
\pm 774 \\
\end{array}$ & $\begin{array}{r}6476 \\
\pm 1289 \\
\end{array}$ & $\begin{array}{l}3978 \\
\pm 225 \\
\end{array}$ & $\begin{array}{c}2798 \\
\pm 1021 \\
\end{array}$ & $\begin{array}{l}3617 \\
\pm 236 \\
\end{array}$ & $\begin{array}{l}2491 \\
\pm 837 \\
\end{array}$ & $\begin{array}{r}2756 \\
\pm 0 \\
\end{array}$ \\
\hline Drink supplier sale & $\begin{array}{r}19840 \\
\pm 2443 \\
\end{array}$ & $\begin{array}{r}1991 \\
+2281 \\
\end{array}$ & $\begin{array}{l}14041 \\
\pm 2433 \\
\end{array}$ & $\begin{array}{l}8960 \\
\pm 797 \\
\end{array}$ & $\begin{array}{l}6447 \\
\pm 1511 \\
\end{array}$ & $\begin{array}{l}8408 \\
\pm 773 \\
\end{array}$ & $\begin{array}{r}5448 \\
\pm 2720 \\
\end{array}$ & $\begin{array}{r}5841 \\
\pm 0 \\
\end{array}$ \\
\hline $\begin{array}{l}\text { Food speaking for } \\
\text { quantity }\end{array}$ & $\begin{array}{l}190755 \\
\pm 2653\end{array}$ & $\begin{array}{l}15723 \\
\pm 2721 \\
\end{array}$ & $\begin{array}{l}151644 \\
\pm 9986 \\
\end{array}$ & $\begin{array}{r}69315 \\
\pm 3709 \\
\end{array}$ & $\begin{array}{l}50620 \\
\pm 1851\end{array}$ & $\begin{array}{r}69000 \\
\pm 4169\end{array}$ & $\begin{array}{r}6073 \\
\pm \quad 4852 \\
\end{array}$ & $\begin{array}{c}76563 \\
\pm 0\end{array}$ \\
\hline Food supply quantity & $\begin{array}{l}174166 \\
\pm 2374\end{array}$ & $\begin{array}{l}14226 \\
\pm 2281\end{array}$ & $\begin{array}{l}138675 \\
\pm 9543\end{array}$ & $\begin{array}{l}64254 \\
\pm 2452 \\
\end{array}$ & $\begin{array}{l}46021 \\
\pm 2386\end{array}$ & $\begin{array}{r}63208 \\
\pm 5461\end{array}$ & $\begin{array}{l}5915 \\
\pm 4814\end{array}$ & $\begin{array}{l}69741 \\
\pm 0\end{array}$ \\
\hline Food supplier cost & $\begin{array}{l}76323 \\
\pm 9000 \\
\end{array}$ & $\begin{array}{r}6529 \\
\pm 911 \\
\end{array}$ & $\begin{array}{l}60693 \\
\pm 5104 \\
\end{array}$ & $\begin{array}{r}28154 \\
\pm 529 \\
\end{array}$ & $\begin{array}{r}20085 \\
\pm 74 \\
\end{array}$ & $\begin{array}{r}27445 \\
\pm 2508 \\
\end{array}$ & $\begin{array}{l}15065 \\
\pm 1591 \\
\end{array}$ & $\begin{array}{r}6577 \\
\pm 0 \\
\end{array}$ \\
\hline Food supplier sale & $\begin{array}{l}167117 \\
\pm 6396 \\
\end{array}$ & $\begin{array}{r}14636 \\
\pm 2695 \\
\end{array}$ & $\begin{array}{r}134746 \\
\pm 9971 \\
\end{array}$ & $\begin{array}{l}61397 \\
\pm 1296 \\
\end{array}$ & $\begin{array}{r}44373 \\
\pm 348 \\
\end{array}$ & $\begin{array}{r}60925 \\
\pm 5281 \\
\end{array}$ & $\begin{array}{l}32879 \\
\pm 5026 \\
\end{array}$ & $\begin{array}{c}67275 \\
\pm 0 \\
\end{array}$ \\
\hline $\begin{array}{l}\text { Rest consumable } \\
\text { speaking for quantity }\end{array}$ & $\begin{array}{l}49911 \\
\pm 8652 \\
\end{array}$ & $\begin{array}{l}2512 \\
\pm 984 \\
\end{array}$ & $\begin{array}{l}40734 \\
\pm 2655 \\
\end{array}$ & $\begin{array}{l}19221 \\
\pm 137 \\
\end{array}$ & $\begin{array}{l}14665 \\
\pm 1011 \\
\end{array}$ & $\begin{array}{l}23220 \\
\pm 560 \\
\end{array}$ & $\begin{array}{r}7676 \\
\pm 3585 \\
\end{array}$ & $\begin{array}{c}15192 \\
\pm \\
\end{array}$ \\
\hline $\begin{array}{l}\text { Rest consumable supply } \\
\text { quantity }\end{array}$ & $\begin{array}{l}45846 \\
\pm 8513\end{array}$ & $\begin{array}{l}2404 \\
\pm 856 \\
\end{array}$ & $\begin{array}{l}37420 \\
\pm 2691 \\
\end{array}$ & $\begin{array}{l}17637 \\
\pm 261 \\
\end{array}$ & $\begin{array}{l}13077 \\
\pm 1043\end{array}$ & $\begin{array}{l}21230 \\
\pm 967 \\
\end{array}$ & $\begin{array}{l}6968 \\
\pm 2750\end{array}$ & $\begin{array}{c}13887 \\
\pm 0\end{array}$ \\
\hline $\begin{array}{l}\text { Rest consumable } \\
\text { supplier cost }\end{array}$ & $\begin{array}{l}19742 \\
\pm 2934\end{array}$ & $\begin{array}{l}1097 \\
\pm 324\end{array}$ & $\begin{array}{l}16108 \\
\pm 1465\end{array}$ & $\begin{array}{r}7460 \\
\pm 1007\end{array}$ & $\begin{array}{r}6527 \\
\pm 709\end{array}$ & $\begin{array}{l}9996 \\
\pm 654\end{array}$ & $\begin{array}{l}2180 \\
\pm 542\end{array}$ & $\begin{array}{r}6577 \\
\pm 0\end{array}$ \\
\hline $\begin{array}{l}\text { Rest consumable } \\
\text { supplier sale }\end{array}$ & $\begin{array}{l}44137 \\
\pm 6875 \\
\end{array}$ & $\begin{array}{l}2267 \\
\pm 698 \\
\end{array}$ & $\begin{array}{l}35655 \\
\pm 3340 \\
\end{array}$ & $\begin{array}{l}16147 \\
\pm 2640 \\
\end{array}$ & $\begin{array}{r}13996 \\
\pm 1914 \\
\end{array}$ & $\begin{array}{l}21107 \\
\pm 1761 \\
\end{array}$ & $\begin{array}{r}5446 \\
\pm 1780 \\
\end{array}$ & $\begin{array}{c}14519 \\
\pm 0 \\
\end{array}$ \\
\hline
\end{tabular}


Supplier management Agent chose the type of supplier by clustering analysis algorithm and speaking for quantity of merchandise. In this paper, Agents simulated the action of three suppliers because there were multi-supplier entities in a type of suppliers. Supplier management Agent sent respectively out information to every supplier. Suppliers responded the request of supplier management Agent and provided synchronously the price of merchandise when suppliers received the information that supplier management Agent sent out [7]. Supplier management Agent analyzed the price and chose classic supplier, which is showed in Fig. 4.

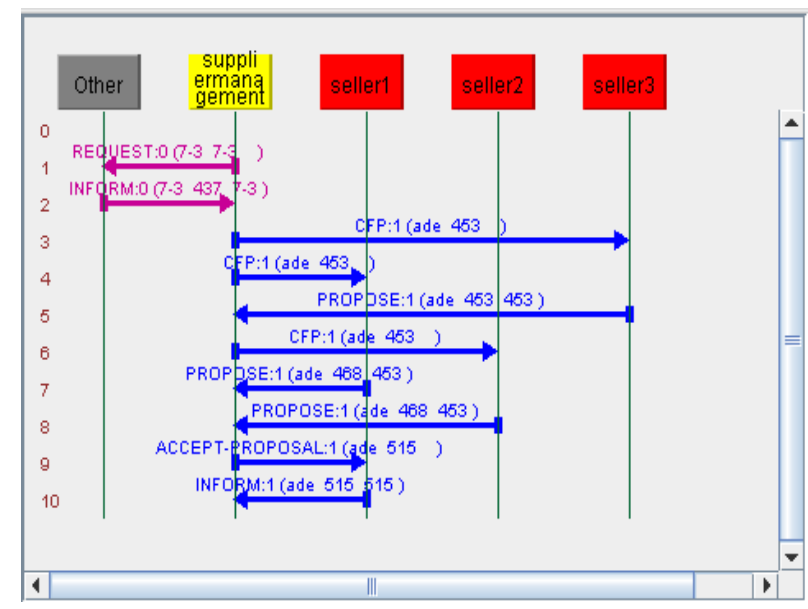

Figure 4. Alternation between supplier management Agent and supplier

\section{CONCLUSION}

With the supplier data of chain supermarket, the supplier business intelligence system was developed based on data warehouse and Agent technique. The advanced technique of business intelligence was applied to business manage, which has management idea of intelligence and optimizing function. By mining fully existing data resource, supermarket corporation user can capture information, analyze information, communicate information and discover many data relations unrecognized to help supermarket corporation governor to make better business decision-making.

\section{REFERENCES}

[1] Michael L.Gonzales, IBM Data Warehousing With IBM Business Intelligence Tools [M], Publishing House Electronics Industry, Beijing, China, 2004.

[2] W.H.Inmon, Building the Data Warehouse [M], Thrid Edition, China Machine Press, Beijing, China, 2004.

[3] Helen Hagan, Peter Hyland, Using OLAP and Multidimensional Data for Decision Making [J], IT Professional, 2001, pp.36-45.

[4] ZhaoHui, TangJamie, Data Mining Concepts and Applications-SQL Server 2005 Database[M], Publishing House Electronics Industry, Beijing, China, 2007.

[5] Jiawei Han, Micheline Kamber, Data Mining Concepts and Techniques [M], High Education Press and Morgan Kaufmann Publisher, 2001.

[6] Nicholas R. Jennings, On agent-oriented software engineering [J], Journal of Artificial Intelligence, 2000, vol. 11, pp. 277-296.

[7] Matthia Kluseh, Information Agent technology for the Intemet: A survey [J], Data \& Knowledge Engineering, 2001, 36: pp. 337-372. 